\title{
Peningkatan Motivasi Belajar Tarikh Melalui Metode CIRC (Cooperative Integrated Reading And Compotition)
}

\author{
Abd. Madjid \\ Universitas Muhammadiyah Yogyakarta \\ madjidabdul.madjid8@gmail.com
}

Anita Aisah

Universitas Muhammadiyah Yogyakarta aisahanita@gmail.com

Naufal Ahmad Rijalul Alam

Universitas Muhammadiyah Yogyakarta naufal.ahmad@,umy.ac.id

\begin{abstract}
Abstrak: This will have a negative impact, one of which is the decline of a sense of appreciation of the history of Islamic figures. The study aims to: (1) analyze the extent of the influence of CIRC (2) to prove whether thereis an increase motivation learning of Tarikh in experimental group treated in the form of cooperative method CIRC when compared to an untreated control group. The type of this research is experimental research using quasi experimental design, untreated control group design pretest and posttest. Statistical methods used to test the hypothesis using anava mixed design or referred to as mixed anava. Anava mixed design combines two sub-analysis with Within Subject Test and Between Subject Test. Within Subject Test is a test of difference of score in one group (pretest vs. posttest) and Between Subject Test is testing difference of score between groups. The results are; 1) There is noSignificant difference in learning motivation in the experimental group before and after treatment of CIRC method, 2) there is no Significant difference in learning motivation between the experimental class and the control class after the CIRC method.
\end{abstract}

Keywords: learning motivation of Tarikh, CIRC, Students

Abstrak: Penelitian ini memiliki tujuan yang meliputi (1) menganalisis peningkatan motivasi belajar Tarikh pada siswa kelas eksperimen sebelum dan sesudah diberikan metode Cooperative Integrated Reading and Compotition (CIRC); (2) menganalisis perbedaan motivasi belajar Tarikh pada kontrol dan kelas eksperimen setelah diberikan metode CIRC. 
Jenis penelitian ini adalah penelitian eksperimen dengan menggunakan desain eksperimen kuasi, untreated control group design pretest and posttest. Analisis statistik yang digunakan untuk menguji dua hipotesis menggunakan anava campuran atau lebih dikenal dengan Anava Mixed Design. Anava Mixed Design ini memadukan dua sub analisis yaitu Within Subject Test dan Between Subject Test. Within Subject Test merupakan pengujian perbedaan jumlah skor dalam satu kelompok (pretest dan posttest) dan Between Subject Test yaitu pengujian perbedaan skor antar kelompok. Hasil penelitian menjelaskan bahwa; 1) Tidak ada perbedaan motivasi belajar Tarikh yang signifikan pada kelompok eksperimen sebelum dan sesudah perlakuan metode CIRC, 2) Tidak ada perbedaan motivasi belajar Tarikh secara signifikan antara kelompok eksperimen dengan kelompok kontrol setelah metode CIRC.

Kata Kunci: Motivasi Belajar Tarikh, Metode Kooperatif CIRC, Siswa

\section{Pendahuluan}

Tujuan pendidikan karakter adalah membentuk siswa beriman, bertaqwa dan mengembangkan kepribadian peserta didik ke arah yang lebih baik atau positif. Tujuan ini dapat terwujud melalui Pendidikan Agama Islam (PAI). PAI memiliki posisi yang sangat strategis dalam mewujudkan karakter tersebut. Tujuan dari PAI yaitu untuk membentuk manusia yang memiliki ketangguhan iman, berkualitas dan berilmu pengetahuan.

Tarikh atau Sejarah Kebudayaan Islam (SKI) merupakan salah satu PAI/kelompok Ismuba. Tarikh/SKI mempelajari tentang sejarah Islam yang memiliki manfaat dan tujuan yang penting bagi kehidupan untuk era sekarang. Apabila kita meninjau salah satu misi dari gerakan Islam Muhammadiyah yaitu menyebarkan ajaran Islam yang bersumber kepada Kitab Allah yaitu Al-Quran, kitab yang terakhir dan sunnah Rasul memiliki fungsi untuk pedoman hidup seluruh umat manusia ${ }^{1}$. Rasul memiliki sebuah sejarah yang sangat penting dipelajari oleh seluruh umat Islam terutama pengikut gerakan Islam Muhammadiyah. Tujuan mempelajari Tarikh/SKI adalah agar dapat diambil suatu pelajaran dari perjuangan dan perjalanan sejarah umat Islam terdahulu, kemudian dapat diambil kesimpulan tentang bagaimana ajaran Islam yang murni $^{2}$

${ }^{1}$ Nn. (2010). Manhaj Gerakan Mubammadiyah, Ideologi, Khittah dan Langkah. Yogyakarta: Suara Muhammadiyah: 12.

2 A. Sumarna, (2013). Pendidikan Tarikh, SMP/MTs Mubammadiyah. Yogyakarta: Majelis Pendidikan: 16 
Motivasi belajar siswa pada mata pelajaran SKI atau tarikh di MTs Muhammadiyah tergolong rendah. Hal ini seperti yang dipaparkan oleh Sardirman menyatakan bahwa: motivasi belajar yang rendah memiliki ciri ciri yaitu tidak menunjukkan kesukaan pada pelajaran Tarikh. Siswa akan terlihat termotivasi dalam belajar adalah ketika senang memberikan umpan balik oleh guru. Siswa kesulitan untuk merespon pertanyaan dari guru setelah dibacakan materi tarikh di kelas VII MTs Muhammadiyah. ${ }^{3}$

Pendidik perlu meningkatkan motivasi belajar Tarikh pada siswa atau peserta didik. Salah satu tujuannya yang hendak dicapai adalah agar dapat mencapai prestasi belajar dan meningkatkan kecintaan siswa pada Islam terutama Rasulnya. Dari hasil asesmen terlihat bahwa guru juga merasa kesulitan mengajar mata pelajaran Tarikh terutama di kelas VIII. Guru pernah menerapkan metode mind map pada siswa, tetapi tidak semua siswa antusias. Dari hasil wawancara guru menyatakan bahwa dalam jangka dua tahun ini guru belum dilatih tentang metode pembelajaran oleh Pendidikan Dasar dan Menengah Pimpinan Daerah Muhammadiyah (Dikdasmen PDM). Metode Pembelajaran yang beberapa kali digunakan oleh pendidik pada mata pelajaran Tarikh adalah ceramah atau konvensional. ${ }^{4}$

Cooperative Integrated Reading and Compotition (CIRC) merupakan salah satu bentuk metode pembelajaran kooperatif. CIRC diterapkan untuk menanamkan pembelajaran kooperatif pada program ketrampilan membaca dan menulis, ${ }^{5}$ Menurut Keshler dalam Metode CIRC adalah kumpulan program membaca, menulis dengan mengunakan pembelajaran tertantu dalam memahami bacaan dengan tulisan. ${ }^{6}$ selanjutnya Selvin memaparkan langkah-langkah dalam pembelajaran CIRC, meliputi:. Membentuk grup atau kelompok beranggotakan 4-5 siswa secara heterogen; Pendidik membacakan bacaan sesuai dengan tema pembelajaran; Siswa saling membacakan dan menemukan gagasan; Mempresentasikan hasil kelompok; Pendidik membuat kesimpulan bersama; dan Penutupan. $^{7}$

Penelitian penerapan CIRC sudah beberapa kali dilakukan oleh ahli pendidikan baik di dalam maupun luar negeri. Berhasil membuktikan bahwa dengan Metode Kooperatif tipe CIRC dapat membentukperilaku aktif belajar

3 A. Aisah, (2013). Penerapan Metode Kooperatif STAD terhadap Motivasi Belajar Bahasa Jawa. Universitas Gadjah Mada: 20

${ }^{4}$ Nashar. (2004). Peranan Motivasi dan Kemampuan Awal dalam Kegiatan Pembelajaran. Jakarta: Delia Press: 32

${ }^{5}$ K. Huda, (2010). Pembelajaran Bahasa Arab Dengan Cooperative Learning. MP A. Surabaya: 42

${ }^{6}$ E. P, Putranto, (2010). Penerapan Model Pembelajaran Kooperatif CIRC Berbantuan Modul untuk Meningkatkean Keaktifan dan Hasil Belajar Siswa Kelas VIILA, MTsN 1 Gemolong Tabun Ajaran 2009/2010. Surakarta: 40

${ }^{7}$ R. E.Slavin, (2010). Cooperative Learning, Teori, Riset dan Praktik. Bandung: Nusa Media,: 54 
dan meningkatkan hasil belajar pada siswa. Menerapkan CIRC untuk meningkatkan pemahaman membaca dan pembelajaran vocabulary. Hasilnya adalah metode CIRC dalam meningkatkan pemahaman membaca pada pelajaran Bahasa Inggris. ${ }^{8}$

Menemukan beberapa hasil penelitian tentang CIRC. Dua dari empat hasil penelitiannya CIRC dapat meningkatkan motivasi siswa untuk memahami bacaan dan metode CIRC lebih efektif meningkatkan motivasi siswa untuk memahami bacaan dibandingkan dengan metode konvensional/ceramah. ${ }^{9}$ CIRC tidak hanya digunakan dalam mata pelajaran Bahasa saja. Penelitian yang dilakukan oleh Susanto adalah menerapkan CIRC pada Minat Belajar Matematika. Hasilnya adalah metode kooperatif CIRC berpengaruh signifikan untuk meningkatkan minat belajar Matematika. Berdasarkan rangkuman hasilhasil penelitian penerapan metode CIRC dapat disimpulkan bahwa metode CIRC lebih efektif dari metode konvensional dalam upaya peningkatan pemahaman bacaan. Metode CIRC juga dapat meningkatkan minat dan hasil belajar. Metode CIRC juga dapat diterapkan pada mata pelajaran selain yang terkait dengan bahasa secara langsung yaitu Matematika.

Apabila ditinjau kembali, tujuan utama CIRC adalah menggunakan kelompok untuk membantu siswa mempelajari kemampuan memahami bahan bacaan yang dapat diterapkan secara tepat. Pada mata pelajaranl Tarikh/SKI siswa dituntut untuk lebih banyak membaca dan memahaminya. Maka penerapan metode koopertif CIRC diharapkan dapat meningkatkan motivasi siswa belajar Tarikh.

Berdasarkan hasil-hasil penelitian tentang pengaruh penerapan metode kooperatif CIRC, maka rumusan masalah pada penelitian ini adalah, apakah ada pengaruh penerapan metode kooperatif CIRC terhadap motivasi belajar Tarikh pada siswa kelas VIII di salah satu Mts Muhammadiyah di Yogyakarta. Penelitian ini bertujuan untuk menganalisis: 1) seberapa signiifikan pengaruh metode kooperatif CIRC terhadap motivasi belajar Tarikh pada siswa kelas VIII di Mts Muhammadiyah Kasihan Bantul Yogyakarta. 2) Apakah terjadi peningkatan motivasi belajar Tarikh pada kelas atau kelompok eksperimen yang distimulasi dengan perlakuan berupa metode kooperatif CIRC jika dibandingkan dengan kelompok kontrol yang diberikan perlakukan metode pembelajaran ceramah atau konvensional.

${ }^{8}$ A. A. Zarei, (2012). The Effect of STAD and CIRC on L2 Reading Comprehention: 23

${ }^{9}$ L. Rahmawati, D. (2014). The Effect of CIRC Strategy and Achievement Motivation Toward Student's Readning Comprehention. E-Journal Program Pascasarjana Universitas Pendidikan Ganesha, 3 . 


\section{Tinjauan Teoritis}

\section{A. Motivasi Belajar Tarikh}

Motivasi merupakan bagian yang sangat kompleks dari kondisi kognitif dan perilaku manusia tntang bagaimana siswa menghabiskan waktunya, seberapa banyak energi yang digunakan untuk mengerjakan tugas, bagaimana mereka berfikir dan merasakan tentang tugasnya dan seberapa lama mereka tetap melakukan tugasnya ${ }^{10}$. Menurut Sadirman asal kata motivasi adalah motif. Sesuatu yang mendorong anak didik untuk melakukan sesuatu untuk mencapai tujuan disebut dengan motif. Motivasi dapat dibedakan menjadi beberapa jenis yaitu motivasi berprestasi atau motivasi belajar, motivasi berkuasa dan motivasi berafilias, motivasi yang terkait dengan kegiatan siswa di sekolah adalah motivasi belajar. ${ }^{11}$

Uno merumuskan tentang motivasi belajar. Motivasi Belajar menurutnya merupakan kekuatan yang timbul oleh karena adanya rangsangan dari internal dan eksternal sehingga siswa memiliki keinginan dalam merubah perilaku atau aktivitas tertentu lebih baik dari kondisi sebelumnya. ${ }^{12}$ Aspek-Aspek Motivasi Belajar menurut Sardirman meliputi: tekun dalam menghadapi tugas; ulet dalam menghadapi kesulitan; Menunjukkan kesukaan pada berbagai macam masalah; lebih senang bekerja secara mandiri;cepat bosan dengan tugas rutin atau hal hal yang bersifat mekanis; dapat mempertahankan pendapat; tidak mudah melepaskan sesuatu yang diyakininya ${ }^{13}$. Motivasi sangat berperan penting dalam proses belajar. Siswa yang mempunyai motivasi yang tinggi, memiliki komitmen dalam belajar serta meraih prestasi yang baik.

Motivasi belajar memiliki kekhususan pada mata pelajaran tertentu. Pada penelitian ini motivasi belajar yang menjadi fokus penelitian adalah motivasi belajar Tarikh. Tarikh adalah salah satu mata pelajaran ISMUBA di Sekolah Muhammadiyah. Mata pelajaran Tarikh terkait dengan sejarah peristiwaperistiwa umat Islam di masa lampau. Jadi motivasi belajar tarikh adalah dorongan yang muncul dari rangsangan internal maupun eksternal sehingga

10 Bakar, R. (2014). The Effect of Learning Motivation on Student's Productive Competencies in Vocational High School, West Sumatra. International Journal of Asian Social Science, 4(6), 722-732.

${ }^{11}$ McClelland, D. C. (2009). Human Motivation. New York: Cambridge University Press: 50

${ }^{12}$ H.B. Uno, (2018). Teori Motivasi dan Pengukurannya. Jakarta: PT. Bumi Aksara: 65

13 F. Daud, (2012). Pengaruh Kecerdasan Emosional (EQ) dan Motivasi Belajar Terhadap Hasil Belajar Biologi Siswa SMA 3 Negeri Kota Palopo. Jurnal Pendidikan Dan Pembelajaran (JPP), 19(2), 243-255. 
siswa berkeinginan untuk meningkatkan maupun merubah perilaku belajar selama proses belajar Tarikh. ${ }^{14}$

\section{B. Metode Pembelajaran Kooperatif CIRC}

Cooperative Integrated Reading and Coompotition (CIRC) adalah bagian dari pembelajaran kooperatif. Slavin telah mengembangkan metode pengajaran membaca yang efektif untuk kelas yang meliputi para siswa yang memiliki kemampuan membaca yang berbeda. CIRC memiliki beberapa manfaat dan tujuan yaitu, menyajikan model aktivitas yang bervariasi dalam pengajaran membaca seperti beberapa latihan dalam aktivitas membaca tingkat dasar, partner membaca, tatabahasa cerita dan menulis berdasarkan cerita dan membaca kosakata baru.

Aspek-aspek pembelajaran kooperatif CIRC sama dengan pembelajaran kooperatif pada umumnya. Aspek-aspeknya terdiri dari: saling ketergantungan positif dalam pembelajaran kelompok, keberhasilan menyelesaikan tugas yang tergantung kepada usaha yang dilakukan setiap anggota kelompok; dan tanggung jawab individu yang merupakan konsekuensi dari prinsip ketergantungan positif. Keberhasilan tergantung pada tanggung jawab setiap anggota, maka setiap anggota kelompok harus memiliki tanggung jawab sesuai dengan tugas masing-masing; Interaksi positif, interaksi positif yang dilakukan melalui interaksi tatap muka akan memberikan pengalaman kepada setiap anggota kelompok untuk saling bekerja sama, menghargai setiap pendapat walaupun berbeda, mengoptimalkan kelebihan masing-masing anggota dan menerima kelemahan masing-masing anggota; Komunikasi yang efektif antar anggota, pembelajaran kooperatif melatih siswa untuk dapat mampu berpartisipasi aktif dalam berkomunikasi; dan pemrosesan kelompok.

Langkah atau tahapan proses pembelajaran dalam metode CIRC yaitu pendidik membagi siswa dalam kelompok untuk merespon suatu wacana dengan langkah-langkah: guru membentuk kelompok yang anggotanya empat atau lima siswa yang heterogen, heterogen ini bisa ditinjau dari prestasi siswa; guru menyampaikan tujuan atau yang ingin dicapai; guru memberikan wacana sesuai dengan tema pembelajaran; siswa diberikan tugas untuk bekerja sama, saling menyimak, saling membacakan, dan menemukan gagasan pokok dan

14 Supri Yanti, Erlamsyah, Zikra, Z. A. (2013). Hubungan Antara Kecemasan Dalam Belajar Dengan Motivasi Belajar Siswa. Konselor: Jurnal Ilmiah Konseling, 2(1), 283-288. https://doi.org/10.24036/02013211242-0-00 
menyampaikan pendapat atau tanggapan; mempresentasikan hasil kelompok; guru membuat kesimpulan bersama; sesi terakhir adalah penutup. ${ }^{15}$

\section{Kerangka Berfikir}

Motivasi belajar Tarikh merupakan dorongan pada siswa untuk meningkatkan tingkah laku agar tercapai tujuan belajar Tarikh. Dorongan dapat berupa intrinsik maupun ekstrinsik. Salah satu dorongan ekstrinsik yang meningkatkan motivasi pada siswa adalah metode pembelajaran yang interaktif yaitu metode CIRC. Melalui metode CIRC, siswa yang belajar Tarikh diajak untuk saling memotivasi siswa sekelompoknya agar meraih juara kelompok. Peningkatan motivasi belajar tarikh terjadi ketika siswa di dalam kelompok saling memotivasi.

\section{Hipotesis}

Hipotesis yang ditetapkan dalam penelitian eksperimen ini yaitu adanya peningkatan yang signifikan motivasi belajar pada kelompok eksperimen. Secara detail hipotesisnya ada dua, yaitu:

1. Skor motivasi belajar Tarikh pada kelompok sesudah perlakuan secara signifikan lebih tinggi dari pada sebelum diberikan perlakuan.

2. Skor motivasi belajar Tarikh pada kelompok perlakuan secara signifikan lebih tinggi secara dari pada kelompok kontrol

\section{Metode Penenelitian}

Penelitian ini tergolong penelitian lapangan (field research). Penelitian lapangan adalah penelitian yang dilakukan melalui pengumpulan data dan informasi yang diperoleh langsung dari partisipan dan mengobservasi secara langsung tugas yang berhubungan dengan tujuan penelitian. Penelitian ini merupakan penelitian kuantitatif eksperimen dengan menggunakan desain eksperimen kuasi, Untreated Control Group Design Pretest and Posttest. Desain pada penelitian memuat satu kelompok/kelas eksperimen dan kelompok/kelas kontrol. Kelompok/kelasperlakuan nantinya akan diberikan perlakuan Metode Pembelajaran CIRC selama pelajaran Tarikh. Pada Kelompok/Kelas kontrol tidak diberikan perlakuan seperti kelompok eksperimen.Pada kelompok kontrol diberikan metode pembelajaran konvensional. berikut ini bagan desain eksperimen:

${ }^{15}$ R.E, Slavin, (2010). Cooperative Learning, Teori, Riset dan Praktik. Bandung: Nusa Media: 
Bagan 1. Bagan Rancangan Eksperimen

\begin{tabular}{c|c|c|c|c|c|c}
\hline Kelompok & & Pretest & & Metode & & Posttest \\
\hline $\mathrm{KE}$ & $\rightarrow$ & $\mathrm{O} 1$ & $\rightarrow$ & $\mathrm{X} 1$ & $\rightarrow$ & $\mathrm{O} 2$ \\
\hline $\mathrm{KK}$ & $\rightarrow$ & $\mathrm{O} 1$ & $\rightarrow$ & $\mathrm{X} 2$ & $\rightarrow$ & $\mathrm{O} 2$ \\
\hline
\end{tabular}

Keterangan:

$\mathrm{KE}$

Kelompok Perlakuan

KK Kelompok Kontrol

X1 Metode Kooperatif CIRC

X2 Metode Ceramah

O1 Pretest

$02 \quad$ Posttest

Teknik penetapan responden pada penelitian ini menggunakan metode pengambilan sampel non probability sampling. ${ }^{16}$ Metode non probability sampling yaitu teknik untuk menentukan sampel dari populasi yang ditentukan yang tidak memberi kesempatan bagi setiap unsur atau anggota dari populasi untuk diputuskan menjadi sampel penelitian. Karakteristik populasinya adalah Siswa yang berusia diatas 12 tahun, (fase perkembangan operasional formal) dan siswa kelas 2 MTs/VIII yang mengikuti mata pelajaran Tarikh dari awal sampai akhir penelitian. Sampel dalam populasi ini adalah siswa kelas VIIIA dan VIIIC MTs Muhammadiyah di Bantul Yogyakarta.

Teknik pengambilan data menggunakan skala dan praktek metode kooperatif CIRC. Skala yang dipakai pada penelitian ini adalah Skala Motivasi Belajar Tarikh. Skala disusun berdasarkan teori motivasi belajar. Skala motivasi belajar aspek dari teori yang dipaparkan Sardirman berikut tabel blue print skala motivasi belajar Tarikh terdiri dari tiga aspek yaitu: adanya keinginan untuk bersungguh-sungguh belajar Tarikh; Siswa erlibat dalam mengerjakan tugas Tarikh yang diberikan; siswa memiliki komitmen untuk terus peningkatkan perilaku positif dalam proses belajar Tarikh. Teknik pelaksanaan eksperimen adalah sebagai berikut: Pendidik membentuk kelompok 4-5 siswa yang heterogen; Pendidik memberikan wacana sesuai dengan topik; siswa bekerja sama saling membacakan dan menemukan ide pokok; Pendidik memberikan reinforcement atau pujian positif; kemudian guru dan siswa sama-sama membuat kesimpulan.

${ }^{16}$ Sugiyono. (2010). Metode Penelitian Kuantitatif Kualitatif dan R\&D. Bandung: Alfabeta: 75 
Metode yang digunakan sebagai pembanding adalah metode pembelajaran ceramah. Ceramah atau lebih sering disebut dengan metode tradisional/konvensional. Sejak zaman dahulu metode ini telah digunakan sebagai metode pembelajaran yang digunakan oleh guru selama proses belajar dan pembelajaran. Pada proses pembelajaran Tarikh, metode pembelajaran cemarah ditunjukkan dengan ceramah yang diiringi dengan penjelasan oleh pendidik, pembagian tugas dan tugas yang diberikan secara individu.

Statistik yang digunakan untuk menguji hipotesis adalah menggunakan Anava Mixed Design. Pada analisis ini di dalamnya terdapat dua analisis yaitu Within Subject Test dengan Between Subject Test. Within Subject Test merupakan pengujian skor dalam satu kelompok (pretest vs posttest) sedangkan Between Subject Test merupakan pengujian perbedaan jumlah skor dalam satu kelompok (pretest vs posttest). Pada Between Subject Test merupakan pengujian perbedaan skor antar kelompok (kelompok perlakuan versus kelompok kontrol). ${ }^{17}$ Analisis data akan dilakukan dengan menggunakan program Statistik SPSS (Statistical Product and Service Solution) versi 17.0.

\section{Hasil Penelitian Dan Pembahasan}

A. Pelaksanaan Pra-Penelitian

Sebelum dilaksanakan penelitian, peneliti menguji validitas dan reliabilitas alat ukur yaitu menguji modul eksperimen dan menguji skala motivasi belajar. Uji Coba Pertama adalah uji coba modul eksperimen. Modul eksperimen diuji cobakan kepada guru Tarikh dan siswa kelas VIII di MTs Muhammadiyah Kasihan yang bukan subjek eksperimen. Uji coba ini dilaksanakan dengan tujuan menguji ketepatan waktu, meninjau materi kemudian mempersiapkan administrasi pelaksanaan eksperimen. Peneliti menggunakan metode profesional judgement untuk menilai uji coba modul.

Uji coba yang kedua adalah uji coba skala motivasi belajar Tarikh. Jenis validitas dalam penelitian terdiri dari validitas kontraks, validitas isi, dan validitas ukuran. Validitas isi dan konstrak dilakukan oleh profesional judgement. ${ }^{18}$

Skala motivasi belajar yang diuji-cobakan adalah sebanyak 36 item kepada 87 siswa. Dari 87 angket hanya 78 angket yang memenuhi syarat uji reliabilitas. Menurut Azwar semua item yang mencapai koefisien korelasi minimal 0,3 daya pembedanya memiliki arti item yang

${ }^{17}$ Hartono. (2011). Statistik Untuk Penelitian. Yogyakarta: Pustaka Pelajar: 32

18 Arikunto, S. (2013). Prosedur Penelitian: Suatu Pendekatan Praktik. Jakarta: Rineka Cipta. 
memuaskan. Koefisien reliabilitas 0,895 yang artinya memiliki reliabilitas yang baik. Berdasarkan hasil analisis dari 36 item didapat 26 item yang baik dan 10 item tidak lolos atau gugur. 10 item yang tidak lolos tersebut mempunyai koefisien indeks daya beda item yang di bawah skor $0,3 .{ }^{19}$

B. Pelaksanaan Eksperimen

Sebelum pelaksanaan eksperimen, peneliti melakukan uji homogenitas untuk menguji tingkat homogenistas dua kelompok penelitian. Hasil uji homogenitas antara pretest kelompok perlakuan (kelas C) dengan pretest kelompok pembanding/kontrol (kelas A) menunjukkan angka 0,064. Hal ini berarti kondisi kelompok eksperimen dan kelompok kontrol adalah homogen, sehingga bisa menjadi landasan perbedaan posttestnya.

Pelaksanaan eksperimen dilaksanakan pada tanggal 1 Januari -8 Februari 2016, menyesuaikan jadwal pelajaran Tarikh di masing masing kelompok. Kegiatan penelitian dilaksanakan di MTs Muhammadiyah Kasihan Bantul. Trainer atau guru dalam pelaksanaan penelitian ini adalah guru Tarikh dari MTs Muhammadiyah Kasihan Bantul. Teknis urutan metode CIRC pada pembelajaran mata pelajaran Tarikh berdasarkan metode CIRC yang dikembangkan oleh Slavin.

Slavin (2010)membagi alur model pembelajaran menjadi lima tahap, meliputi: Tahap Pertama, yaitu orientasi. Pada Tahap ini pendidik melakukan apersepsi dan pemberian informasi awal siswa tentang tema pelajaran yang diberikan. Selain itu juga memaparkan tujuan pembelajaran yang dilakukan kepada siswa; Tahap Kedua, yaitu organisasi. Pada fase organisasi pendidik membagi siswa ke dalam beberapa kelompok dengan memperhatikan keheterogenan akademik. pendidik juga membagikan bahan bacaan dan tema yang akan dipelajari dengan siswa. Selain itu menjelaskan mekanisme atau teknis diskusi kelompok dan tugas yang harus dilaksanakan selama proses pembelajaran CIRC berlangsung; Tahap Ketiga, Pengenalan Konsep. Tahap ini mengenalkan suatu gagasan baru yang bersifat untuk mengeksplorasi. Pengenalan ini bisa didapat dari keterangan pendidik, film, buku paketkliping, poster atau media yang lain; Tahap Keempat yaitu Tahap Presentasi atau Publikasi. Tahap presentasi ini siswa mempresentasikan hasil diskusi di kelompoknya, memperagakan, membuktikan tentang materi yang dibahas dalam kelompok. Presentasi dilakukan oleh individu yang mewakili kelompok. Tahap terakhir yaitu Tahap Penguatan dan Refleksi. Pada tahap ini pendidik memberikan 
beberapa tambahan materi yang telah didiskusikan melalui penjelasan atau memberikan contoh.

Pada kelompok kontrol diterapkan metode pembelajaran konvensional. Metode pembelajaran konvensional merupakan metode pembelajaran ceramah atau disebut juga dengan metode konvensional. Metode ini sering digunakan oleh pendidik karena tidak perlu persiapan yang rumit. Namun pada dasarnya metode ceramah ini sering digunakan, hanya saja guru harus kreatif memodifikasi metode ceramah dengan dicampur dengan metode yang lain.

\section{Hasil Penelitian}

Dari hasi pretest dan posttest didapatkan bahwa terjadi peningkatan skor motivasi belajar Tarikh pada 9 siswa, skor tetap pada 1 siswa sedangkan 7 siswa mengalami penurunan. Di bawah ini adalah grafik pretest dan posttest pada kelompok eksperimen:

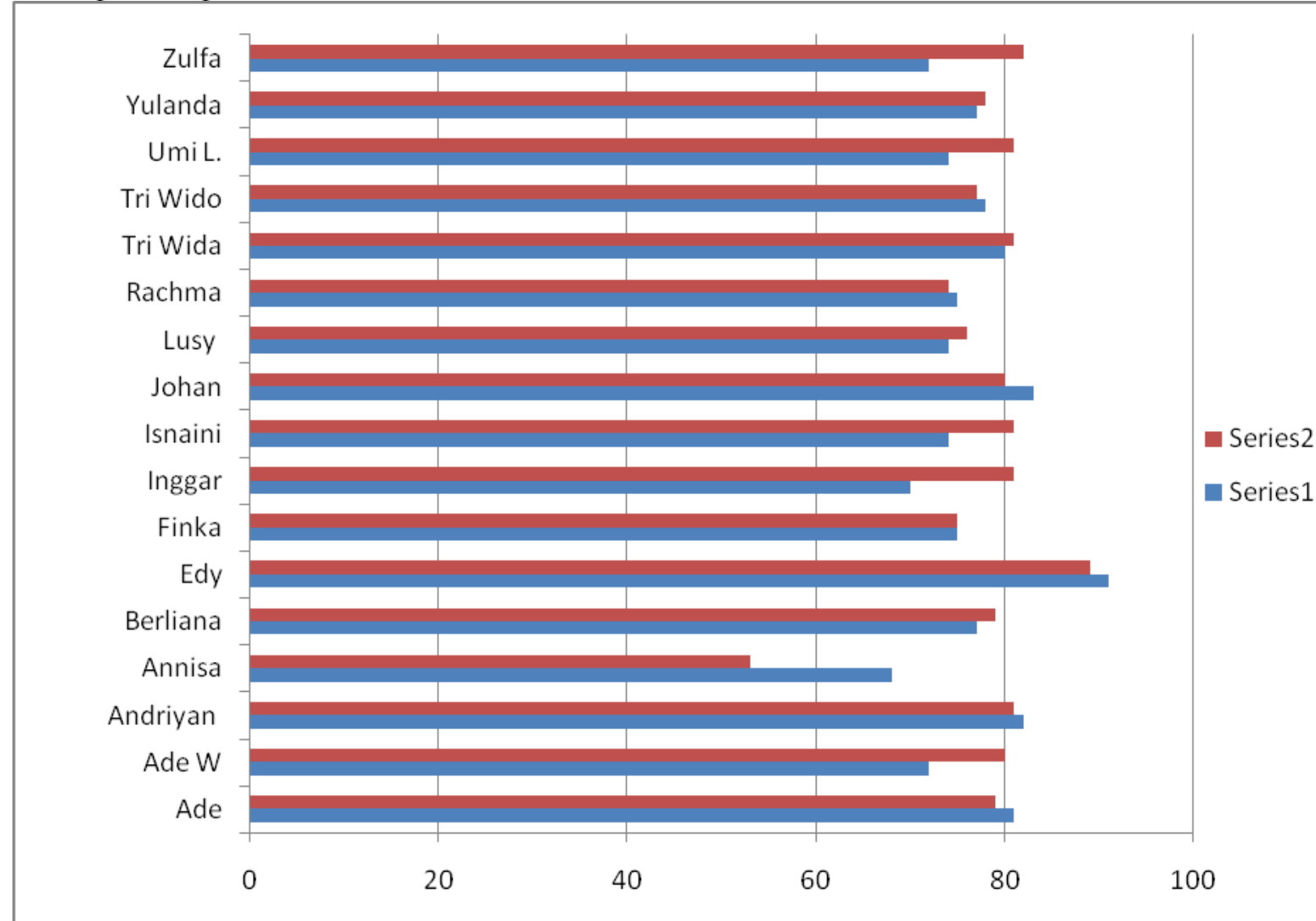


Pada kategorisasi kelompok eksperimen terlihat bahwa terjadi perubahan kelompok dari pretest ke posttest yaitu pada kategori sedang dan tinggi. Pada pretest menunjukkan bahwa kategori pretest lebih banyak dibandingkan posttest, tetapi pada posttest malah sebaliknya. Pada posttest kategori tinggi lebih banyak dari pada kategori sedang.

Hasil uji hipotesis 1 yaitu perbedaan motivasi belajar kelompok perlakuan sebelum dan sesudah perlakuan menunjukkan angka sig 0,125. Hal ini menunjukkan bahwa tidak ada perbedaan yang signifikan pada kelompok/kelas eksperimen antara motivasi belajar sebelum dan sesudah perlakuan. Walaupun tidak terjadi perbedaan yang signifikan, mean motivasi belajar sesudah perlakuan $(77,06)$ lebih tinggi dari pada mean motivasi belajar sebelum perlakuan $(74,00)$.

Hasil uji hipotesis 2 yaitu perbedaan motivasi belajar pada / kelas eksperimen dan kelas kontrol setelah perlakuan menunjukkan angka sig 0,614. Hal ini menunjukkan bahwa tidak ada perbedaan signifikan pada kelompok/kelas eksperimen dan kelompok/kelas kontrol sesudah diberikanperlakuan. Walaupun tidak terjadi perbedaan yang signifikan, mean motivasi belajar kelompok eksperimen $(77,06)$ secara signifikan lebih tinggi dari pada mean motivasi belajar kelompok kontrol $(72,15)$.

Selanjutnya penelitian ini memiliki tujuan untuk membuktikan efektivitas metode CIRC terhadap motivasi belajar Tarikh. Hasil analisis dari penelitian ini adalah metode CIRC tidak menunjukkan pengaruh yang signifikan pada peningkatan motivasi. Pada penelitian ini, motivasi belajar tarikh memang meningkat terlihat dari peningkatan mean setelah penerapan perlakuan metode CIRC. Namun peningkatan mean tersebut tidak signifikan. Motivasi belajar Tarikh berperan sangat penting dalam mencapai tujuan belajar agar dapat membantu siswa dalam memahami makna dan manfaat dari belajar itu sendiri. Motivasi belajar adalah suatu dorongan supaya individu bersemangat untuk belajar. Motivasi belajar tarikh sangat penting untuk dipelihara dan ditingkatkan karena untuk membudayakan siswa cinta sejarah Islam. ${ }^{20}$ Salah satu cara adalah dengan meningkatkan motivasi eksternal melalui metode pembelajaran yang menyenangkan. Banyak faktor yang mempengaruhi motivasi belajar. Dari sekian banyak faktor tersebut adalah upaya Pendidik dalam peningkatan keaktifan siswa dalam belajar. ${ }^{21}$ Hamalik mengatakan, bahwa usaha pendidik dalam menggerakkan motivasi belajar siswa misalnya pembentukan tugas bersama di dalam kelompok. Di dalam teori psikologi pola kerja kelompok masuk ke dalam

${ }^{20}$ A. Karim. (2014). Meningkatkan Motivasi Belajar Pendidikan Sejarah Kebudayaan Islam (SKI) Melalui Metode Pembelajaran Mind Mapping. Quality Journal, 1(2).

${ }^{21}$ Mudjiono dan Dimyati. (2006). Belajar dan Pembelajaran. Jakarta: Raja Grafindo Persada: 
konstruksivisme sosial. Siswa membentuk atau mempelajari suatu konsep dengan saling bertukar pikiran.

Pada kondisi di lapangan, peneliti kesulitan memilih teori pada mata pelajaran Tarikh untuk diaplikasikan pada metode CIRC. Guru Tarikh menggunakan tiga buku. Tiga buku yang dijadikan acuan, alur dan isinya tidak ada yang hampir sama mengenai materi yang akan diberikan. Selain itu beberapa peristiwa, penulisan tahun di tiga buku tersebut juga berbeda. Hal ini menyebabkan acuan bacaan yang diberikan pada siswa juga berbeda. Selain itu buku pedoman Tarikh tidak boleh dibawa pulang oleh siswa, sehingga siswa tidak bisa membaca buku tersebut di rumah.

Menurut Slavin, metode CIRC memiliki beberapa kekurangan yaitu persiapan yang harus dilakukan pendidik. Pendidik yang akan menerapkan metode pembelajaran kooperatif membutuhkan banyak waktu dan terlihat rumit. Hal ini terjadi pada penelitian. Proses persiapan yang dilakukan oleh pendidik dan peneliti membutuhkan waktu yang lama. Pada setiap tema pembelajaran menggunakan buku yang berbeda. Kemudian kelemahan CIRC selanjutnya adalah kurang adanya tanggung jawab individual. Selama eksperimen pada beberapa siswa yang menggantungkan proses diskusi dan presentasi dengan siswa lain di kelompoknya. Dari hasil observasi siswa-siswa yang mengagungkan diri dengan siswa lain merupakan siswa yang memiliki prestasi di bawah ratarata.

Peneliti sudah berusaha menggunakan metode mind map di dalam penerapan metode CIRC selama proses eksperimen. Metode mind map ini telah diuji oleh Karim yang hasilnya mampu meningkatkan motivasi belajar Tarikh. Peneliti tidak bisa menggunakan metode media visual melalui video, karena sekolah tidak memfasilitasi. Metode video ini telah terbukti untuk meningkatkan ketrampilan membaca.

Selama proses penerapan metode CIRC, kelas yang ditempati oleh kelompok eksperimen juga kurang memadai. Kelas kelompok eksperimen yaitu kelas VIIIC letaknya persis di depan kantin. Jadwal mata pelajaran Tarikh juga dijadwalkan pada jam keempat dan kelima sebelum istirahat kedua. Selama empat kali ekperimen sebelum pelajaran selesai, peneliti melihat beberapa siswa beberapa kali melihat keluar. Suasana di luar adalah beberapa siswa kelas lain yang istirahat di kantin. Kegaduhan ini terlihat sangat mengganggu suasana belajar di kelas kelompok eksperimen.

Kondisi penerangan di ruang kelas juga kurang memenuhi. Ketika siswa presentasi di depan kelas (fase publikasi), tulisannya tidak terlihat jelas oleh siswa yang duduk paling belakang. Lampu ruangan terlihat kurang terang. Sehingga pada fase publikasi, tidak berjalan optimal. Guru sebagai trainer penelitian ini sudah bersemangat dan menjalankan tugas sesuai dengan rencana. Namun ada satu kali sesi eksperimen (di hari keempat) yang jadwalnya bersamaan dengan 
kelas lain. Dalam hal ini, peneliti dan asisten peneliti bisa membuat suasana eksperimen menjadi optimal.

\section{Kesimpulan}

Setelah melalui eksperimen dan analisis statistik, maka penelitian ini memiliki beberapa kesimpulan: pertama, tidak ada perbedaan motivasi belajar Tarikh yang signifikan pada kelompok perlakuan/ eksperimen sebelum dan sesudah perlakuan metode CIRC dan tidak ada perbedaan motivasi belajar Tarikh yang terbukti secara signifikan antara kelompok/kontrol eksperimen dan kelompok/kelas kontrol setelah metode CIRC. Kedua, Metode CIRC tidak dapat meningkatkan motivasi belajar Tarikh secara signifikan.

Keterbatasan penelitian ini adalah adanya sumber pembelajaran Tarikh yang berbeda antara peneliti dengan guru Tarikh. Selain itu guru Tarikh masih menggunakan buku yang berbeda pada setiap bab. Sehingga dapat disarankan adanya modul pembelajaran Tarikh yang dapat menjadi acuan belajar di Sekolah Menengah Pertama baik itu sekolah Islam maupun negeri. 


\section{Bibliografy}

A. Karim. (2014). Meningkatkan Motivasi Belajar Pendidikan Sejarah Kebudayaan Islam (SKI) Melalui Metode Pembelajaran Mind Mapping. Quality Journal, 1(2).

Aisah, A. (2013). Penerapan Metode Kooperatif STAD terhadap Motivasi Belajar Bahasa Jawa. Universitas Gadjah Mada.

Arikunto, S. (2013). Prosedur Penelitian: Suatu Pendekatan Praktik. Jakarta: Rineka Cipta.

Azwar, S. (2004). Penyusunan Skala Psikologi. Yogyakarta: Pustaka Pelajar.

Bakar, R. (2014). The Effect of Learning Motivation on Student's Productive Competencies in Vocational High School, West Sumatra. International Journal of Asian Social Science, 4(6), 722-732.

Daud, F. (2012). Pengaruh Kecerdasan Emosional (EQ) dan Motivasi Belajar Terhadap Hasil Belajar Biologi Siswa SMA 3 Negeri Kota Palopo. Jurnal Pendidikan Dan Pembelajaran (JPP), 19(2), 243-255.

Hamalik, O. (2005). Manajemen Pengembangan Kurikulum. Bandung: PT. Remaja Rosda Karya.

Hartono. (2011). Statistik Untuk Penelitian. Yogyakarta: Pustaka Pelajar.

Huda, K. (2010). Pembelajaran Bahasa Arab Dengan Cooperative Learning. MPA. Surabaya.

Ida Ayu Nym. Sri Santini, I Kt. Adnyana Putra, I. G. A. O. N. (2014). PENGARUH PEMBELAJARAN KOOPERATIF CIRC BERBANTUAN MEDIA VISUAL TERHADAP KETERAMPILAN MEMBACA PADA BAHASA INDONESIA SISWA KELAS IV SD GUGUS II TAMPAKSIRING. E-Journal Mimbar PGSD Universitas Pendidikan Ganesha Jurusan PGSD, 2(1).

L. Rahmawati, D. (2014). The Effect of CIRC Strategy and Achievement Motivation Toward Student's Readning Comprehention. E-Journal Program Pascasarjana Universitas Pendidikan Ganesha, 3.

McClelland, D. C. (2009). Human Motivation. New York: Cambridge University Press.

Mudjiono dan Dimyati. (2006). Belajar dan Pembelajaran. Jakarta: Raja Grafindo Persada.

Nashar. (2004). Peranan Motivasi dan Kemampuan Awal dalam Kegiatan Pembelajaran. Jakarta: Delia Press.

Nn. (2010). Manhaj Gerakan Muhammadiyah, Ideologi, Khittah dan Langkah. Yogyakarta: Suara Muhammadiyah.

Putranto, E. P. (2010). Penerapan Model Pembelajaran Kooperatif CIRC Berbantuan Modul untuk Meningkatkan Keaktifan dan Hasil Belajar Siswa Kelas VIILA, MTsN 1 Gemolong Tahun Ajaran 2009/2010. Surakarta. 
Slavin, R. E. (2010). Cooperative Learning, Teori, Riset dan Praktik. Bandung: Nusa Media.

Sugiyono. (2010). Metode Penelitian Kuantitatif Kualitatif dan R\&D. Bandung: Alfabeta.

Sumarna, A. (2013). Pendidikan Tarikh, SMP/MTs Muhammadiyah. Yogyakarta: Majelis Pendidikan Dasar dan Menengah, Pimpinan Wilayah Muhammadiyah, Daerah Istimewa Yogyakarta.

Supri Yanti, Erlamsyah, Zikra, Z. A. (2013). Hubungan Antara Kecemasan Dalam Belajar Dengan Motivasi Belajar Siswa. Konselor: Jurnal Ilmiah Konseling, 2(1), 283-288. https://doi.org/10.24036/02013211242-0-00

Susanto, H. (2009). Implementasi Metode CIRC (Cooperative Integrated Reading and Composition) Dalam Pembelajaran Matematika ditinjau dari Minat Belajar. Universitas Muhammadiyah Surakarta.

Uno, H. B. (2018). Teori Motivasi dan Pengukurannya. Jakarta: PT. Bumi Aksara.

William R. Shadish, Thomas D. Cook, D. T. C. (2002). Experimental and Quasi Experimentak Design for Generalized Causal Inference. Boston: Houghton Mifflin Company.

Zarei, A. A. (2012). The Effect of STAD and CIRC on L2 Reading Comprehention and Vocabolary Learning. Fronties of Language and Teaching, 3, 161-173. 